\title{
2007 Florida Citrus Pest Management Guide: Asian Citrus Psyllid and Citrus Leafminer ${ }^{1}$
}

M.E. Rogers and P.A. Stansly ${ }^{2}$

\section{Asian Citrus Psyllid}

\section{Psyllid Management}

With citrus greening disease (Huanglongbing) now present in Florida, management of the Asian citrus psyllid (Diaphorina citri Kuwayama) has become very important. In other regions of the world where citrus is grown and greening disease is present, use of insecticides to control the psyllid vector has been a major component of greening management strategies. No scientific data has been collected in these countries to demonstrate that insecticide use provides a benefit in terms of reducing or slowing the spread of greening disease. However, anecdotal evidence suggests that reducing psyllid populations via insecticide application may help to slow the rate of spread of the disease. It should be noted that elimination of the disease from an area has never been successful.

\section{Factors Affecting Psyllid Populations}

The two main factors that affect the abundance of psyllids are 1) presence of new flush and 2) temperature. New flush is required for psyllid females to lay eggs as well as for subsequent development of the psyllid nymphs. When no new flush is present, psyllids populations do not continue to increase. During this time of no new flush, adult psyllids can be found feeding on the underside of leaves. The ability to survive for long periods in the absence of new flush allows psyllids to over-winter on hardened-off leaves. These overwintering psyllids will then lay eggs on new flush that is present in the early spring.

Temperature is also closely linked to the abundance of psyllids in the field. The ideal temperature conditions for psyllids are between $68-86^{\circ} \mathrm{F}$. At these temperatures, a single female psyllid lives for 30-50 days and can lay between 300 and 800 eggs. When the daily temperatures are above $90^{\circ} \mathrm{F}$, the average lifespan of a female psyllid

1. This document is ENY-734, one of a series of the Entomology and Nematology Department, Florida Cooperative Extension Service, Institute of Food and Agricultural Sciences, University of Florida. Date printed: November 2006. This publication is included in SP-43, 2007 Florida Citrus Pest Management Guide. A copy of this publication may be found at http://edis.ifas.ufl.edu/IN686. Please visit the EDIS Web site at http://edis.ifas.ufl.edu. For a copy of this handbook, request information on its purchase at your county extension office.

2. M.E. Rogers, assistant professor, Entomology and Nematology Department, Citrus REC, Lake Alfred, Florida; and P.A. Stansly, professor, Entomology and Nematology Department, Southwest Florida REC, Immokalee, Florida; Cooperative Extension Service, Institute of Food and Agricultural Sciences, University of Florida, Gainesville, 32611.

The use of trade names in this publication is solely for the purpose of providing specific information. UF/IFAS does not guarantee or warranty the products named, and references to them in this publication does not signify our approval to the exclusion of other products of suitable composition. 
decreases to less than 30 days with an average of fewer than 70 eggs produced per female. Thus, under Florida conditions, psyllid populations will be substantially lower during the mid summer months due to both high temperatures and a reduced amount of new flush available for egg laying. If insecticides are to be used for psyllid suppression, they should be applied earlier in the year when conditions are favorable for rapid buildup of psyllid populations. During the summer months, when temperatures and flush patterns are not favorable for psyllid development, insecticide applications made solely for psyllid management are less likely to be beneficial in terms of reducing psyllid populations. Predators and parasitoids of the psyllids are more likely to provide increased levels of control during these periods of low psyllid populations.

\section{Psyllid Feeding Damage and Disease Transmission}

Psyllid feeding damage is limited to new growth resulting in curling of the young leaves due to the withdrawal of plant fluids. Because of the nature of this damage, in the absence of citrus greening disease, past control recommendations were targeted to young trees on which the new flush comprised a significant portion of the total leaf canopy. While it is unlikely that pesticide application and other management strategies targeting psyllids will provide complete control of greening, efforts to manage psyllid populations (together with removal of trees that are visibly infected with greening) will be necessary to slow the spread of the disease in groves where present.

Much of the information on transmission of the citrus greening pathogen by the Asian citrus psyllid is still uncertain. Previous studies on psyllid-pathogen transmission suggests that a healthy psyllid feeding on a greening infected plant may be able to pick up the pathogen with as little as 30 minutes of feeding. After picking up the bacteria, a latent period which may last up to 25 days is required before the psyllid can transmit the pathogen. Transmission of the pathogen is thought to occur through salivary secretions, requiring 1-7 hours of feeding for successful transmission to occur. More detailed studies are needed to confirm these reports and determine the exact nature of transmission and whether psyllid-pathogen transmission might be prevented or delayed by the use of insecticides.

Because psyllids and the disease cannot be completely eliminated from Florida citrus, the goal of psyllid management is suppression of psyllid populations, not total eradication of the insect or pathogen. To effectively maintain psyllids at low levels throughout the year, it will be necessary to incorporate chemical, cultural and biological control into a comprehensive management strategy for psyllid suppression. No one management strategy alone is likely to be able to provide the results desired in terms of reducing psyllid populations. Thus, managing psyllids will involve targeting control measures at appropriate times depending on the particular growing situation.

\section{Nonbearing Trees}

Young trees that produce multiple flushes throughout the year are at greater risk of greening infection than mature trees because of the attraction of adult psyllids to the new flush. Even without greening, young trees in the field need to be protected for about 4 years from psyllids and leafminers to grow optimally. Soil-applied systemic insecticides will provide the longest lasting control of psyllids with the least impacts on beneficials. Drenches are best applied once in the spring or summer and again in the fall, when the trees are flushing and rainfall is less likely to move the material past the root zone before it can be taken up by the plant. Foliar sprays with different modes of action can be used during the rainy season if psyllids are observed on the new flush of young trees. When making multiple foliar insecticide applications within a season, rotation between products with different modes of action is recommended to reduce the likelihood of pesticide resistance development.

\section{Bearing Trees}

Management options for psyllid control on bearing trees are much more limited than for non-bearing trees. Currently, the only soil-applied insecticide that has been shown to provide any reduction in psyllid numbers on large trees is aldicarb. If aldicarb is applied to bearing trees as part 
of a program for psyllid management, application should be made at least 30 days prior to the initiation of flushing. This timing will allow for the material to move from the roots up to the tree canopy.

At present, the only other chemical control option for suppressing psyllids on bearing trees is the use of broad-spectrum foliar insecticide applications. If greening is present in a grove or nearby, the best timing of foliar sprays for psyllid control is during the early season flush periods when temperatures are at or below $90^{\circ} \mathrm{F}$ and psyllids are most abundant. Foliar sprays should be timed to the presence of feather-leaf flush. Successfully controlling psyllids with foliar sprays on large trees is difficult because of the unsynchronized sporadic flushing patterns within a grove and the short-residual effects of these foliar sprays. Successful suppression of psyllids during the early part of the year may result in lower populations throughout the rest of the summer when psyllids populations do not develop rapidly due to the higher temperatures, limited availability of new flush and a greater abundance of natural enemies.

\section{Biological Control}

Foliar insecticide applications should be used sparingly to minimize the impact on natural enemies that maintain psyllids at lower levels later in the year. While a single female psyllid can lay as many as 800 eggs, studies in Florida and Puerto Rico have shown that over $90 \%$ of psyllids that hatch in the field do not survive to become adults. Many are consumed by predaceous insects such as ladybeetles. The parasitic wasp, Tamarixia radiata, has been released in Florida and also contributes some mortality. Additionally, there are many potential pests such as scales, mealybugs, whiteflies, etc. that are generally innocuous in Florida citrus due to biological control. Excessive sprays could easily result in resurgence of psyllids and other pests.

\section{Other Management Considerations}

In groves where citrus greening has been confirmed, trees showing signs of infection should be removed quickly. Foliar insecticides that provide quick knockdown of psyllids should be sprayed on the infected tree(s) prior to removal to prevent further spread of the pathogen by psyllids.
Otherwise, the greening infected psyllids will disperse from the tree(s) being removed and infest nearby healthy trees. Be sure to follow re-entry interval (REI) directions on the pesticide label. Trees in the immediate vicinity of infected trees should be considered higher risk due to increased likelihood of infection and receive extra scouting and treatment if necessary.

Management practices used within a grove can also affect psyllid populations, especially those practices that promote new flush such as hedging and topping and fertilization. Management strategies that reduce or limit the duration of flush, may help to keep psyllid populations at low levels and reduce the need for additional pesticide applications. Alternate host plants surrounding citrus can serve as a source of psyllids for infestation. Two common host plants include orange jasmine (Murraya paniculata) and box orange (Severinia buxifolia). Orange jasmine is a preferred host plant for psyllids and is also likely to be a host for the greening pathogen. Box orange is also a host for both the psyllid and the greening pathogen. When possible, both of these plant species should be removed from areas surrounding commercial citrus groves.

\section{Citrus Leafminer}

The adults of the citrus leafminer (Phyllocnistis citrella) are tiny moths that hide within the canopy during the day and emerge at night to lay eggs individually on young, expanding leaf flushes. The egg first appears as a tiny dew drop, usually alongside the midvein on the underside of an unexpanded leaf. The larva emerges directly into the leaf tissue, mining first along the midvein, then back and forth as it makes its way to the leaf margin where pupation occurs.

Leafminer populations decline to their lowest levels during the winter, due to cool temperature and the lack of flush for larval development. Populations of leafminer build rapidly on the spring flush, although their presence is not apparent until late spring as populations increase while the amount of new foliage decreases. Throughout the ensuing warm seasons, leafminer populations vary with the flushing cycles and subsequent flushes are often severely 
damaged. The summer period of high leafminer damage coincides with the rainy season when canker spread is most likely.

Citrus leafminer greatly exacerbates the severity of citrus canker caused by Xanthomonas axonopodis pv. citri. This insect is not a vector of the disease. Nevertheless, leafminer tunnels are susceptible to infection much longer than mechanical wounds. Tunnels infected by canker produce many times the amount of inoculum than in the absence of leafminer. Control of leafminer should be optimized in areas where infection by canker is high. Natural enemies already present in Florida have responded to leafminer infestations, causing in excess of $50 \%$ mortality of larvae and pupae in some areas. The introduced parasitoid Ageniaspis citricola has established throughout most of Florida, with rates of apparent parasitism reaching $90 \%$ or more. However, these high rates of parasitism are not seen until late in the year.

\section{Leafminer Management}

\section{Nonbearing Trees}

On young trees, use of the soil-applied systemic insecticide imidacloprid is the most effective means of preventing mining damage on the new flush and has little direct effect on natural enemies. Soil drenches directly to the base of the tree with imidacloprid have been shown to provide at least 8 weeks control of leafminer. Injection through the irrigation system is less effective because a large portion of the material falls beyond the root zone. Compared to soil-applications of imidacloprid, foliar-applied insecticides provide a shorter duration of protection lasting only about 2 weeks depending on weather conditions and the uniformity of flush pattern.

Soil applications of imidacloprid should be made about 2 weeks prior to leaf expansion to allow time for the pesticide to move from the roots to the canopy. Avoid applications 24 hours prior to significant rainfall events which will result in movement of the product out of the root zone before it can be taken up by the plant. Because of limits on the amount of imidacloprid that may be applied on a per acre basis each season, only one application in the spring and possibly one in the fall are recommended. When the residual effects of the spring application have worn off, typically during the mid-summer rainy season, foliar sprays can be used on small trees to reduce leafminer damage. Reapplication of soil-applied imidacloprid is not recommended during this season because of the likelihood of the material being washed away by frequent summer rains. Foliar sprays should be timed to coincide with the appearance of the first visible leaf mines which occur immediately following the feather leaf stage or about 13 days after budbreak. At this time, insecticide applications will provide protection for most of the leaves in the new flush.

\section{Bearing Trees}

If canker is present in a grove (or in a nearby grove), healthy trees with leafminer damaged leaves are more likely to become sites for new canker infection. The only products currently available for leafminer control on large trees are foliar insecticide sprays. Soil applications of imidacloprid are not effective for leafminer control on large trees due to use rate restrictions that limit the usefulness of the product on trees greater than 6-8 feet in height. It should also be noted that aldicarb $\left(\right.$ Temik $\left.^{\circledR}\right)$, which has been demonstrated to suppress psyllid populations on large trees, does not provide control of leafminers. While there are a number of products that are effective for controlling leafminer, achieving control of leafminer using foliar sprays on large trees is difficult due to the unsynchronized flush typically encountered during the summer period when leafminer populations are at their highest levels.

Since leafminers affect only developing leaves, coverage of peripheral leaves in the canopy should be adequate to exert suppression when applying foliar pesticides.

\section{Recommended Chemical Controls}

\section{READ THE LABEL.}

Some product labels specify rates per acre, while others specify rates per volume delivered (e.g. per 100 gallons). Refer to label for details on how product should be mixed for desired targets. 
Rates for pesticides are given as the maximum amount required to treat mature citrus trees unless otherwise noted. When treating smaller trees with commercial application equipment including handguns, mix the per acre rate for mature trees in 250 gallons of water. Calibrate and arrange nozzles to deliver thorough distribution and treat as many acres as this volume of spray allows.

Table 1. Recommended Chemical Controls for Asian Citrus Psyllids

\begin{tabular}{|c|c|c|c|c|}
\hline Pesticide & $\begin{array}{l}\text { IRAC } \\
\text { MOA }^{1}\end{array}$ & $\begin{array}{l}\text { Mature Trees } \\
\text { Rate/Acre }^{2}\end{array}$ & Comments & Other Pests Controlled \\
\hline Admire $2 \mathrm{~F}$ & 4 & $\begin{array}{l}16 \text { to } 32 \mathrm{fl} \mathrm{oz} \\
\text { per grove acre } \\
\text { OR } \\
1 / 8 \text { oz per tree } \\
\text { (4-6' height) }\end{array}$ & $\begin{array}{l}\text { Soil applied systemic intended primarily for use } \\
\text { on young trees. Apply prior to or at onset of } \\
\text { pest infestation for optimal results. See label for } \\
\text { application options. Do not apply more than } 32 \\
\text { oz/acre/year. }\end{array}$ & Aphids, citrus leafminer \\
\hline Provado 1.6F & 4 & $\begin{array}{l}10 \text { to } 20 \mathrm{fl} \mathrm{oz} \\
\text { per acre }\end{array}$ & Foliar-applied systemic & Aphids \\
\hline Danitol 2.4EC & 3 & $1 \mathrm{pt}$ & Restricted use pesticide. Highly toxic to bees. & $\begin{array}{l}\text { Flower and orchid thrips, } \\
\text { adult root weevils }\end{array}$ \\
\hline Lorsban 4EC & $1 \mathrm{~B}$ & $5 \mathrm{pt}$ & $\begin{array}{l}\text { Restricted use pesticide. May increase spider } \\
\text { mite populations. }\end{array}$ & $\begin{array}{l}\text { Mealybug, orangedog, } \\
\text { katydids, grasshoppers, } \\
\text { aphids, thrips }\end{array}$ \\
\hline Temik $15 \mathrm{G}$ & $1 \mathrm{~A}$ & $33 \mathrm{lb}$ & $\begin{array}{l}\text { Restricted use pesticide. Notification of intent } \\
\text { to apply is required. Application permitted only } \\
\text { between Nov. } 15 \text { and Apr. } 30 \text {. See label for } \\
\text { application restrictions. When psyllid control is } \\
\text { required, apply at least } 30 \text { days prior to } \\
\text { anticipated flush. }\end{array}$ & $\begin{array}{l}\text { Citrus nematodes, citrus } \\
\text { rust mites, aphids, } \\
\text { psyllids }\end{array}$ \\
\hline \multicolumn{5}{|c|}{$\begin{array}{l}{ }^{1} \text { Mode of action class for citrus pesticides from the Insecticide Resistance Action Committee (IRAC) Mode of Action } \\
\text { Classification V4.2.1 (2005). Refer to ENY624, Pesticide Resistance and Resistance Management, in the } 2007 \text { Florida Citrus } \\
\text { Pest Management Guide for more details. } \\
{ }^{2} \text { Lower rates may be used on smaller trees. Do not use less than the minimum label rate. }\end{array}$} \\
\hline
\end{tabular}


Table 2. Recommended Chemical Controls for Citrus Leafminer (Nonbearing/Young Bearing Citrus)

\begin{tabular}{|c|c|c|c|c|}
\hline Pesticide & $\begin{array}{l}\text { IRAC }^{1} \\
\text { MOA }^{1}\end{array}$ & $\begin{array}{c}\text { Mature Trees } \\
\text { Rate/Acre }^{2}\end{array}$ & Comments & $\begin{array}{l}\text { Other Pests } \\
\text { Controlled }\end{array}$ \\
\hline Admire $2 \mathrm{~F}$ & 4 & $\begin{array}{c}16 \text { to } 30 \mathrm{fl} \mathrm{oz} \\
\text { per grove acre } \\
\text { OR } \\
1 / 8 \text { oz per tree } \\
(4-6 \text { ' height })\end{array}$ & $\begin{array}{l}\text { Soil applied systemic intended primarily for } \\
\text { use on young trees. Apply prior to or at onset } \\
\text { of pest infestation for optimal results. See } \\
\text { label for application options. Do not apply } \\
\text { more than } 32 \text { oz/acre/year. }\end{array}$ & $\begin{array}{l}\text { Aphids, citrus } \\
\text { psyllid }\end{array}$ \\
\hline $\begin{array}{l}\text { Agri-Mek } 0.15 \text { EC + } \\
\text { Petroleum Oil } 97+\% \\
\text { (FC } 435-66, F C 455-88, \\
\text { or } 470 \text { oil) }\end{array}$ & 6 & $\begin{array}{c}5 \mathrm{oz}+ \\
\min \text { of } 1 \mathrm{gal}\end{array}$ & $\begin{array}{l}\text { Restricted use pesticide. Do not apply within } \\
7 \text { days of harvest. Do not apply within } 30 \text { days } \\
\text { of last treatment. Do not make more than } 3 \\
\text { applications or apply more than } 40 \mathrm{fl} \\
\text { oz/growing season. No more than } 1 \\
\text { application per year recommended to avoid } \\
\text { pest resistance. Always apply with } \\
\text { horticultural spray oils as directed. Do not } \\
\text { apply in citrus nurseries. Do not apply by } \\
\text { aircraft. } 470 \text { weight oil has not been evaluated } \\
\text { for effects on fruit coloring or ripening. These } \\
\text { oils are more likely to be phytotoxic than } \\
\text { lighter oils. }\end{array}$ & $\begin{array}{l}\text { Citrus rust mites, } \\
\text { citrus bud mite, } \\
\text { broad mite } \\
\text { (See ENY } 603 \text { for } \\
\text { appropriate rates) }\end{array}$ \\
\hline Assail 70 WP & 4 & $2 \mathrm{oz}$ & Do not apply within 7 days of harvest. & \\
\hline $\begin{array}{l}\text { Micromite 80WGS + } \\
\text { Petroleum Oil } 97+\% \\
\text { (FC } 435-66, \text { FC } 455-88 \text {, } \\
\text { or } 470 \text { oil) }\end{array}$ & 15 & $6.25 \mathrm{oz}$ & $\begin{array}{l}\text { Restricted use pesticide. Up to three } \\
\text { applications per season. See restrictions on } \\
\text { the label. Do not apply when temperatures } \\
\text { exceed } 94^{\circ} \mathrm{F} .470 \text { weight oil has not been } \\
\text { evaluated for effects on fruit coloring or } \\
\text { ripening. These oils are more likely to be } \\
\text { phytotoxic than lighter oils. }\end{array}$ & $\begin{array}{l}\text { Citrus root weevils, } \\
\text { citrus rust mites }\end{array}$ \\
\hline $\begin{array}{l}\text { Petroleum Oil } 97+\% \\
\text { (FC } 435-66, F C 455-88, \\
\text { or } 470 \text { oil) }\end{array}$ & $\mathrm{NR}^{3}$ & $5 \mathrm{gal}$ & $\begin{array}{l}\text { Do not apply when temperatures exceed } \\
94^{\circ} \mathrm{F} .470 \text { weight oil has not been evaluated } \\
\text { for effects on fruit coloring or ripening. These } \\
\text { oils are more likely to be phytotoxic than } \\
\text { lighter oils. }\end{array}$ & \\
\hline Spintor 2SC & 5 & $6 \mathrm{oz}$ & Limit of 2 applications per season. & Orangedog \\
\hline \multicolumn{5}{|c|}{$\begin{array}{l}{ }^{1} \text { Mode of action class for citrus pesticides from the Insecticide Resistance Action Committee (IRAC) Mode of Action } \\
\text { Classification V4.2.1 (2005). Refer to ENY624, Pesticide Resistance and Resistance Management, in the } 2007 \text { Florida Citrus } \\
\text { Pest Management Guide for more details. } \\
{ }^{2} \text { Lower rates may be used on smaller trees. Do not use less than the minimum label rate. } \\
{ }^{3} \text { No resistance potential exists for these products. }\end{array}$} \\
\hline
\end{tabular}

